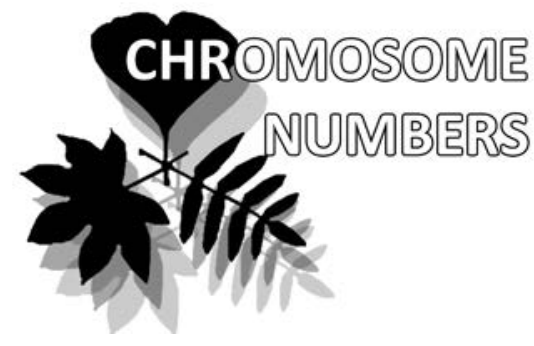

Nina S. Probatova ${ }^{1 *}$

e-mail: probatova@ibss.dvo.ru

Sergei V. Prokopenko ${ }^{1}$

e-mail: sergeyprokopenko@rambler.ru

Olga Yu. Zavgorodnyaya $a^{2,3}$

e-mail: olya.zavgorodnyaya.97@mail.ru

Denis A. Krivenko $2,4,5$

e-mail: krivenko.irk@gmail.com

\author{
${ }^{1}$ Federal Scientific Center of the East Asia \\ Terrestrial Biodiversity FEB RAS, \\ Vladivostok, Russia \\ ${ }^{2}$ Western Baikal Protected Areas, Irkutsk, \\ Russia \\ ${ }^{3}$ Irkutsk State University, Irkutsk, Russia \\ ${ }^{4}$ Siberian Institute of Plant Physiology \& \\ Biochemistry SB RAS, Irkutsk, Russia \\ ${ }^{5}$ National Research Tomsk State \\ University, Tomsk, Russia
}

*corresponding author

Manuscript received: 02.10.2019

Review completed: 29.10.2019

Accepted for publication: 31.10 .2019

Published online: 02.11.2019

\section{Chromosome numbers in some vascular plant species from Altai Region, Baikal Siberia and Primorskii Territory (Russia)}

\author{
Nina S. Probatova ${ }^{1 *}$, Sergei V. Prokopenko ${ }^{1}$,
}

Olga Yu. Zavgorodnyaya ${ }^{2,3}$ \& Denis A. Krivenko ${ }^{2,45}$

\begin{abstract}
A B S T R A C T
The chromosome numbers (2n) for 44 vascular plant species of 43 genera from 21 families: Alliaceae, Apiaceae, Asteraceae, Boraginaceae, Brassicaceae, Cannabaceae, Caryophyllaceae, Chenopodiaceae, Convallariaceae, Fabaceae, Hypecoaceae, Iridaceae, Lamiaceae, Liliaceae, Melanthiaceae, Plantaginaceae, Poaceae, Ranunculaceae, Rosaceae, Scrophulariaceae, Violaceae from Siberia (Altaiskii Krai, Irkutskaya Oblast', Republic of Buryatia) and from the Russian Far East (Primorskii Krai) are presented. The $\mathrm{CN}$ is first studied in Trigonotis peduncularis Benth. ex S. Moore et Baker. The first CN counts from Russia - for Amblynotus rupestris (Pall. ex Georgi) Popov ex Serg. and Phragmites stenophyllus (Boiss.) Rouy ex Prain, from Asiatic Russia - for Arenaria serpyllifolia L., from Siberia - for Turritis glabra L. Eight species - Aquilegia sibirica Lam., Berteroa incana (L.) DC., Cannabis ruderalis Janisch., Dactylis glomerata L., Elymus caninus (L.) L., Lycopus exaltatus L. f., Plantago salsa Pall., Setaria pumila (Poir.) Roem. et Schult. are studied for the first time from Altai, Bupleurum bicaule Helm, Conioselinum tataricum Hoffm. - first from Baikal Siberia, Neotorularia humilis (C.A. Mey.) Hedge et J. Léonard and Minuartia laricina (L.) Mattf. - from Primorskii Krai. In Suaeda kulundensis Lomon. et Freitag the new cytotype $2 \mathrm{n}=36(4 \mathrm{x})$ is found. In Puccinellia tenuissima (Litv. ex V.I. Krecz.) Litv. ex Pavlov also the tetraploid cytotype is revealed: $2 \mathrm{n}=28$ (4x); both new cytotypes are from Altai.
\end{abstract}

K e y w o r d s : chromosome numbers, vascular plants, Siberia, Altaiskii Krai, Irkutskaya Oblast', Republic of Buryatia, Far East, Primorskii Krai, Russia

\section{P E 3 Ю M E}

Пробатова Н.С., Прокопенко С.В., Завгородняя О.Ю., Кривенко А.А. Числа хромосом некоторых виАов сосудистых растений с Алтая, из Байкальской Сибири и Приморского края (Россия). ПривоАятся числа хромосом (2n) Аля 44 вилов флоры А^тая (Западная Сибирь), Прибайкалья и Забайкалья (Восточная Сибирь), Приморского края (Аальний Восток), из 43 родов и 21 семейства: Alliaceae, Apiaceae, Asteraceae, Boraginaceae, Brassicaceae, Cannabaceae, Caryophyllaceae, Chenopodiaceae, Convallariaceae, Fabaceae, Hypecoaceae, Iridaceae, Lamiaceae, Liliaceae, Melanthiaceae, Plantaginaceae, Poaceae, Ranunculaceae, Rosaceae, Scrophulariaceae, Violaceae. Впервые исслеАован в кариологическом отношении Trigonotis peduncularis Benth. ex S. Moore et Baker, впервые Аля России - Amblynotus rupestris (Pall. ex Georgi) Popov ex Serg. и Phragmites stenophyllus (Boiss.) Rouy ex Prain, а Аля азиатской части России - Arenaria serpyllifolia L.; впервые Аля Сибири исследован Turritis glabra L., а Аля Байкальской Сибири - Bupleurum bicaule Helm и Conioselinum tataricum Hoffm., впервые Аля А^тая - Aquilegia sibirica Lam., Berteroa incana (L.) DC., Cannabis ruderalis Janisch., Dactylis glomerata L., Elymus caninus (L.) L., Lycopus exaltatus L. f., Plantago salsa Pall., Setaria pumila (Poir.) Roem. et Schult.; Аля Приморского края впервые - Neotorularia bumilis (C.A. Mey.) Hedge et J. Léonard и Minuartia laricina (L.) Mattf. Y Suaeda kulundensis Lomon. et Freitag установлено новое Аля вила число хромосом $2 \mathrm{n}=36$, а у Puccinellia tenuissima (Litv. ex V.I. Krecz.) Litv. ex Pavlov - 2n = 28: оба новых 4х цитотипа - с А^тая.

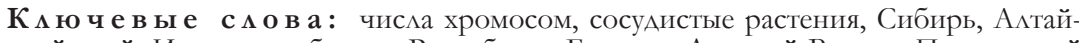
ский край, Иркутская область, Республика Бурятия, Аальний Восток, Приморский край
Here we submit new results of chromosome number $(\mathrm{CN})$ studies on vascular plants from Russia: 44 species mainly from Siberia, and also from the Russian Far East (RFE) - Primorskii Krai, or Primorye (Fig. 1). This contribution continues the series of previous publications by N.S. Probatova et al. Chromosome countings were made on squashed preparations of root tips fixed with Carnoy's solution. The root tips were taken mostly from seedlings obtained through herbarium specimens, or living plants collected in the field. Preparations were stained with iron hematoxylin. Voucher specimens are preserved in the VLA herbarium, Vladivostok or in the NS herbarium, Novosibirsk, some also in the IRK herbarium, Irkutsk. First $\mathrm{CN}$ data are indicated by asterisk $(*)$. The number of the dot on the map follows the number of voucher specimen. Brief information on the species studied is given. 


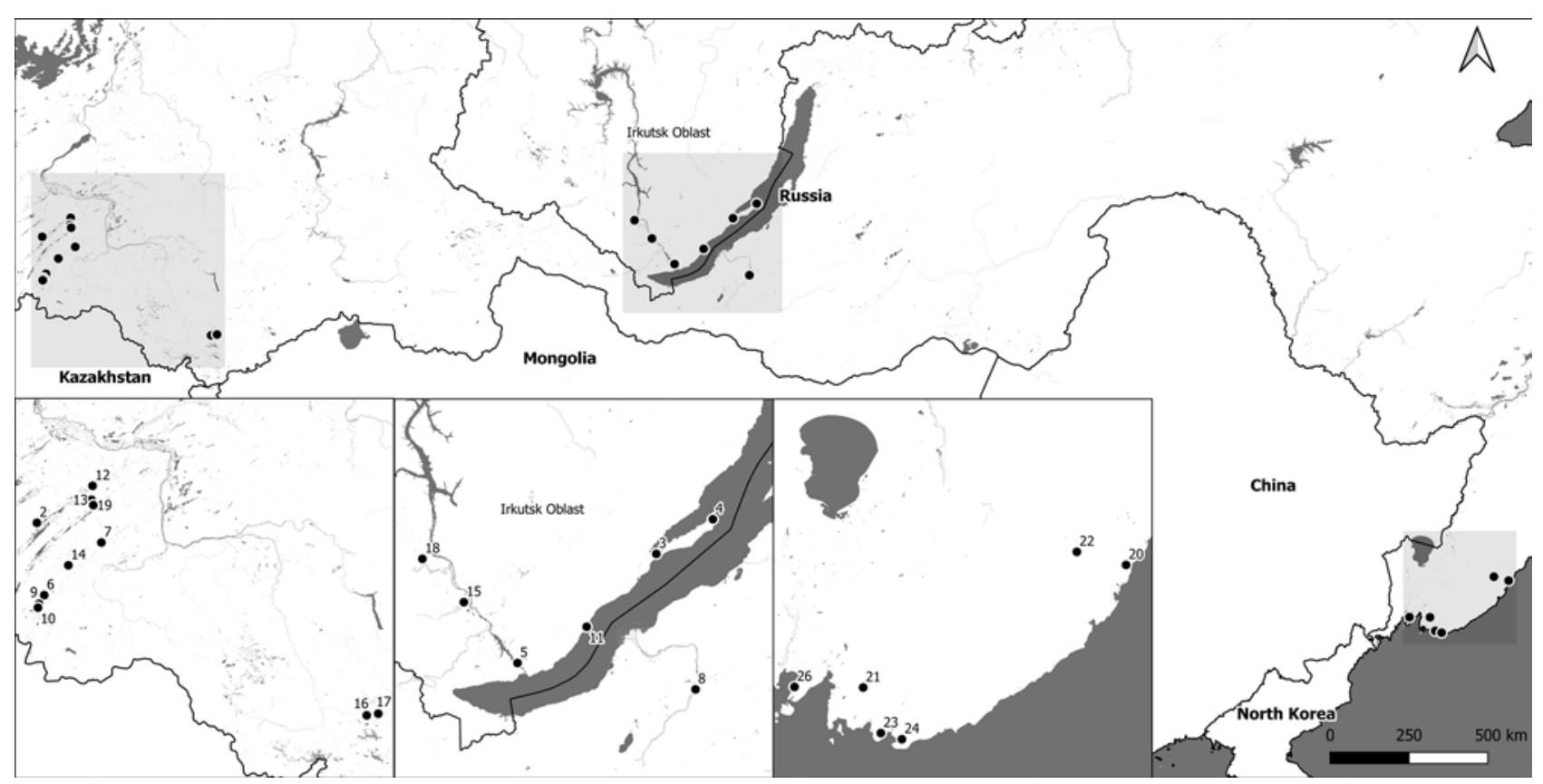

Figure 1 Study area. Dots with numbers from 1 to 26 are the sampling plot locations (according to numbering in the text)

\section{ALLIACEAE}

Allium splendens Willd. ex Schult. et Schult. f., 2n = 16

Russia, East Siberia, Irkutskaya Oblast', Slyudyanskii Raion, W coast of the Baikal Lake, 94th kilometer of Krugobaikal'skaya railway road, right riverside of the Pylovka River, $524 \mathrm{~m}$ alt., in forest, 11 Sep 2018, coll. O.Yu. Zavgorodnyaya 13373: 1 (IRK, VLA).

\section{$-2 n=32$}

Russia, Far East, Primorskii Krai, Kavalerovskii Raion, right riverside of Zerkal'naya River, near the Lake Zerkal'noe, $100 \mathrm{~m}$ alt., upper part of $\mathrm{N}$ slope, oak forest with Rhododendron and Lespedeza, scarce, 6 Aug 2018, coll. S.V. Prokopenko 13293: 20 (VLA).

Distribution: Central and East Siberia, Far East; East Asia. In light forests, among shrubs, meadows, stony slopes and slide rocks, to upper forest belt. Described from Siberia. This species was studied many times, and it is a real polymorphic complex: its CNs vary significantly, especially in Baikal Siberia, where $2 \mathrm{n}=16$ was the most common (see Chepinoga 2014), but also polyploid CNs occur: $2 \mathrm{n}=32,40,48$. Such $\mathrm{CN}$ variability was revealed in $A$. splendens also in the Russian Far East, but the tetraploid CN 2n $=32$ there was obviously more common $(2 \mathrm{n}=16,32,64-$ see Probatova et al. 2007, Probatova 2014, and unpublished data). Species with variable ploidy $(2 \mathrm{x}, 4 \mathrm{x}, 5 \mathrm{x}, 6 \mathrm{x}, 8 \mathrm{x} ; \mathrm{x}=8)$.

\section{APIACEAE}

\section{Bupleurum bicaule Helm, 2n $=22$}

Russia, East Siberia, Irkutskaya Oblast', Ol'khonskii Raion, the Baikal Lake, NE part, Ol'khon Island, near Uzury settlement, $595 \mathrm{~m}$ alt., steppe, 19 Oct 2018, coll. O.Yu. Zavgorodnyaya 13387: 4 (VLA).

Distribution: Siberia; NE Kazakhstan, Central Asia (Mongolia), East Asia (China). In mountain stony steppes, stony and rubbly slopes, rare on rocks. Described from Kras- noyarsk, lectotype - from Altai. Extremely variable as to its CNs: 2n = 12, 22, 24, 28, 32, 36 (see Pimenov \& Ostroumova 2012). First report of $\mathrm{CN}$ from Baikal Siberia.

Carum buriaticum Turcz., $2 \mathrm{n}=22$

Russia, East Siberia, Irkutskaya Oblast', Slyudyanskii Raion, W coast of the Baikal Lake, 94th kilometer of Krugobaikal'skaya railway road, right riverside of the Pylovka River, 456 m alt., lakeside, 14 Sep 2018, coll. O.Yu. Zavgorodnyaya 13374: 1 (IRK, VLA).

Distribution: Siberia, Central Asia (Mongolia), East Asia (China). Meadows, steppes, stony slopes. Described from Transbaikalia. From Altai and from the Baikal Siberia the CN $2 \mathrm{n}=22$ was already reported (see Chepinoga 2014). Diploid $(2 \mathrm{x} ; \mathrm{x}=11)$.

\section{Conioselinum tataricum Hoffm., 2n $=22$}

Russia, East Siberia, Irkutskaya Oblast', Slyudyanskii Raion, W coast of the Baikal Lake, 94th kilometer of Krugobaikal'skaya railway road, right riverside of the Pylovka River, $636 \mathrm{~m}$ alt., in forest, 12 Sep 2018, coll. O.Yu. Zavgorodnyaya 13369: 1 (IRK, VLA).

Distribution: Central and East Europe, Siberia, Middle Asia (mountains), Kazakhstan, Central Asia (Mongolia), East Asia (China). Dark coniferous, mixed and deciduous forests, among shrubs, in meadows, along riversides. Described from West Siberia. The CN 2n = 22 was reported from Novosibirskaya Oblast', Altai, Krasnoyarskii Krai, Khakassia and Tyva Republics (see Goldblatt \& Johnson 1979+, Rice et al. 2014). First CN count from the Baikal Siberia. Diploid $(2 \mathrm{x} ; \mathrm{x}=11)$.

\section{ASTERACEAE}

Iva xanthiifolia Nutt. (三 Cyclachaena xanthiifolia (Nutt.) Fresen.), $2 \mathrm{n}=36$

Russia, West Siberia, Altaiskii Krai, Romanovskii Raion, $3 \mathrm{~km} \mathrm{SE}$ of Romanovo settlement, weedy-ruderal plant 
community, 27 Sep 2018, coll. D.A. Krivenko 13352: 2 (IRK, VLA).

Distribution: N American species, alien in Russia and elsewhere: Siberia - Altaiskii Krai, Far East - Khabarovskii Krai (near Khabarovsk), Primorskii Krai; West and East Europe, Caucasus, Middle Asia. As a weed near plantations and farms, waste areas, railway embankments. Described from America. This $\mathrm{CN}$ is the second count from Siberia: earlier its CN was studied in Altaiskii Krai (Krasnikov et al. 2003). Tetraploid $(4 x ; x=9)$.

\section{BORAGINACEAE}

Amblynotus rupestris (Pall. ex Georgi) Popov ex Serg. (三 Eritrichium rupestre (Pall. ex Georgi) Bunge), 2n = 48

Russia, East Siberia, Irkutskaya Oblast', Olkhonskii Raion, near Sakhyurta settlement, W coast of the Baikal Lake, $514 \mathrm{~m}$ alt., stony steppe, 12 Sep 2018, coll. D.A. Krivenko 13361: 3 (IRK, VLA).

Distribution: Siberia, Central Asia (Mongolia), East Asia (China). Stony and rubbly desert slopes, steppes. Described from Dahuria. Second CN report for the species, but first - in Russia: earlier it was studied in China (Ma et al. 1990). Tetraploid (4x; $x=12)$.

\section{Brachybotrys paridiformis Maxim. ex Oliv., $2 \mathrm{n}=24$}

Russia, Far East, Primorskii Krai, Shkotovskii Raion, in vicinity of Novonezhino settlement, Sapfirova canyon, broad-leaved valley forest, abundant, 25 May 2019, coll. E.P. Kudryavtseva \& S.V. Prokopenko 13416: 21 (VLA).

Distribution: Far East - S Primorye; East Asia - NE China, Korean Peninsula. Umbrageous leaved forests in river valleys. Described from China. Poorly studied species: this is the third CN count, all from Primorye. Diploid (2x; $x$ =12). The $\mathrm{CN} 2 \mathrm{n}=24$ is constant.

*Trigonotis peduncularis Benth. ex S. Moore et Baker, $2 n=24$

Russia, Far East, Primorskii Krai, Muravyov-Amurskii Peninsula, Vladivostok, near Akademgorodok, forest margin, at roadside, 29 May 2019, coll. E.B. Volynets 13404: 26 (VLA).

Distribution: Far East - Amur, Primorye; E Europe, Siberia, Middle Asia, Central Asia (Mongolia), Himalayas, East Asia (China). On plantations, fallows, dry grassy areas, among shrubs. Described from near Astrakhan. This is first $\mathrm{CN}$ count for the species. Diploid $(2 \mathrm{x} ; \mathrm{x}=12)$.

\section{BRASSICACEAE}

\section{Alyssum lenense Adams, $2 \mathrm{n}=16$}

Russia, East Siberia, Irkutskaya Oblast', O’lkhonskii Raion, the Baikal Lake, Ol'khon Island, Uzury settlement, $711 \mathrm{~m}$ alt., steppe, 2 Oct 2018, coll. O.Yu. Zavgorodnyaya 13366: 4 (VLA).

Distribution: East Europe, Siberia, Central Asia (Mongolia), East Asia (Northern China). Steppe stony and sandy slopes, pine steppe forests. Described from Yakutia. Diploid $(2 x ; x=8)$. This is the third $C N$ count from Baikal Siberia, all of them $2 \mathrm{n}=16$ (see Chepinoga 2014).

\section{Berteroa incana (L.) DC., 2n = 16}

Russia, West Siberia, Altaiskii Krai, Rubtzovskii Raion, near Bezrukavka village, left riverside of the Alei River, forb- bluegrass steppe meadow, 18 Sep 2018, coll. D.A. Krivenko 13408: 10 (VLA).

Distribution: Europe, Caucasus, Siberia, Far East (alien), Middle and Central Asia (Mongolia), West China. Riversides, as a weed on abandoned fields, fallows, roadsides, in settlements. Described from N Europe. Diploid $(2 x ; x=8)$. Many $C N$ reports, mostly from Europe, from the Russian Far East, but only one was from Siberia (see Goldblatt \& Johnson 1979+, Rice et al. 2014). The CN 2n $=16$ is constant. This is first $\mathrm{CN}$ count from Altai.

Neotorularia humilis (C.A. Mey.) Hedge et J. Léonard (三 Braya bumilis (C.A. Mey.) B.L. Rob., Torularia bumilis (C.A. Mey.) O.E. Schulz), 2n $=42$

Russia, Far East, Primorskii Krai, Kavalerovskii Raion, near Kavalerovo settlement, nature monument "Dersu Rock", calcareous rocks, 3 Aug 2018, coll. S.V. Prokopenko 13299: 22 (VLA).

Distribution: Siberia, Far East (very rare, with disjunctions); Middle Asia, Central Asia (Mongolia), Himalayas, East Asia (China), N America. Rubbly slide-rocks, sandy and pebble riverside banks, in steppes, on calcareous rocks, outcrops of limestone. Described from Altai. Only two localities of this species in Primorskii Krai. In the Arctic it is represented by subspecies - Braya humilis subsp. arctica (Böcher) Rollins, with the same CN 2n $=42$. Hexaploid $(6 \mathrm{x} ; \mathrm{x}=7)$, but in whole - variable ploidy: $2 \mathrm{n}=42,56$ (see Bolkhovskikh et al. 1969). Its $\mathrm{CN}$ is firstly studied in Primorskii Krai.

\section{Turritis glabra L., 2n = 12}

Russia, East Siberia, Irkutskaya Oblast', Irkutskii Raion, $51 \mathrm{st} \mathrm{km}$ of the Baikal'skii route, right side of the Angara River, 462 m alt., afforested riverside, 20 Aug 2018, coll. D.A. Krivenko 13351: 5 (IRK, VLA).

Distribution: Europe, Caucasus, Siberia, Far East (alien); West and Central Asia, East Asia, North America, Australia (alien). In steppe and forest belts, sandy meadows, stony slopes, riverside pebbles, sometimes as a weed on railway embankments, fallows and vegetable gardens. Described from Europe. Diploid $(2 x ; x=6)$. Several CN counts from Europe (see Goldblatt \& Johnson 1979+, Rice et al. 2014). First CN count from Siberia.

\section{CANNABACEAE \\ Cannabis ruderalis Janisch., $2 \mathrm{n}=20$}

Russia, West Siberia, Altaiskii Krai, Rubtzovskii Raion, outskirts of Mamontova settlement, weedy-ruderal plant communities, 20 Sep 2018, coll. D.A. Krivenko 13354: 6 (VLA).

Distribution: Europe, Asia. As a weed in forest plantations, riversides, roadsides, settlements. There are two $\mathrm{CN}$ reports $(2 \mathrm{n}=20)$ from Siberia (Novosibirskaya Oblast', Krasnoyarskii Krai - Krasnikov \& Shaulo 1990, Stepanov \& Muratova 1995). Diploid $(2 x ; x=10)$. First $C N$ report from Altai.

\section{CARYOPHYLLACEAE}

Arenaria serpyllifolia $\mathrm{L}$., $2 \mathrm{n}=20$

Russia, Far East, Primorskii Krai, Nakhodka city, near bus stop, on the slope oriented towards Nakhodkinskii Prosp., 23 Jun 2017, coll. S.V. Prokopenko 13287: 23 (VLA). 
Distribution: Europe, Caucasus, Siberia, Far East (alien in Primorye - Dal'negorsk, Anisimovka, Nakhodka), Middle Asia and Asia Minor, Mediterranea, as alien in East Asia, N America, Australia. Roadsides and near settlements. Described from Europe. The first report from Asiatic part of Russia. For this species more often $2 \mathrm{n}=40$ was reported, or $2 \mathrm{n}=20,40$ (see Goldblatt \& Johnson 1979+, Rice et al. 2014). Variable ploidy?

\section{Minuartia laricina (L.) Mattf., $2 n=26$}

Russia, Far East, Primorskii Krai, Partisanskii Raion, in vicinity of Khmylovka village, $840 \mathrm{~m}$ alt., the ridge of Chernyi Kust Mt., the slope, near the top, frequent, 5 Jul 2019, coll. S.V. Prokopenko 13414: 24 (VLA).

Distribution: East Siberia, Far East - Amur, Primorye, N Sakhalin; East Asia - NE China, Korea. On rocks, screes, stony slopes, in steppes, Pinus and Pinus-Larix forests. Described from Siberia. In the Far East it was studied from Amurskaya Oblast': $2 \mathrm{n}=26$ (Probatova et al. 2006). First $\mathrm{CN}$ count from Primorye.

\section{CHENOPODIACEAE}

Atriplex laevis C.A. Mey., $2 \mathrm{n}=36$

Russia, East Siberia, Irkutskaya Oblast', Cheremkhovskii Raion, near the village Khudorozhkina, ruderal community, 12 Oct 2018, coll. D.A. Krivenko 13407: 18 (IRK, VLA).

Distribution: West Siberia, Kazakhstan, Central Asia (Mongolia). Saline habitats, moist meadows, riversides. Described from Kazakhstan? Two CNs were revealed: $2 \mathrm{n}=18$ from Baikal Siberia and Altai (Lomonosova et al. 2001, Probatova et al. 2012) and $2 \mathrm{n}=36$ - from Novosibirskaya Oblast' and Mongolia (Lomonosova \& Krasnikov 1992, Lomonosova et al. 2003). Variable ploidy.

\section{Chenopodium album L., 2n = 54}

Russia, West Siberia, Altaiskii Krai, Rebrikhinskii Raion, between Voronikha and Rozhnev Log settlements, plantations of Pinus sylvestris, 27 Sep 2018, coll. D.A. Krivenko 13406: 19 (IRK, VLA).

Distribution: almost cosmopolite (excl. the Arctic). Ruderal habitats, as a weed on plantations, vegetable gardens, roadsides, fallows. Described from Europe. Multiple $\mathrm{CN}$ counts from the world (in Siberia - from Altaiskii Krai, Novosibirskaya Oblast', Tyva Republic, Krasnoyarskii Krai, and Baikal Siberia) (see Goldblatt \& Johnson 1979+, Rice et al. 2014). However not all CNs reported in the literature could be referred to Ch. album, but only $2 \mathrm{n}=54$ (Lomonosova 2018). Hexaploid (6x; $x=9)$.

\section{Suaeda kulundensis Lomon. et Freitag, 2n $=36^{*}$}

Russia, West Siberia, Altaiskii Krai, Aleiskii Raion, 2 km W of the railway station Yazevka Sibirskaya, right riverside of the Sukhnev Log River (left tributary of the Yazevka River), forb-grass saline steppe, 24 Sep 2018, coll. D.A. Krivenko 13353: 7 (IRK, VLA).

Distribution: SE Europe, W Siberia, N Kazakhstan, NW China. Steppe zone. Previous reports indicated that this species has two ploidy levels: octoploid 2n $=72$ (Lomonosova \& Freitag 2009, Lomonosova 2018) and decaploid $2 \mathrm{n}=90$ (Lomonosova \& Shaulo 2010). Now we added the third $-4 \mathrm{x}$ cytotype $(2 \mathrm{n}=36)$. Variable ploidy $(4 \mathrm{x}, 8 \mathrm{x}, 10 \mathrm{x})$.

\section{CONVALLARIACEAE}

Polygonatum involucratum (Franch. et Sav.) Maxim., $2 \mathrm{n}=18$

Russia, Far East, Primorskii Krai, Shkotovskii Raion, in vicinity of Novonezhino settlement, Sapfirova canyon, oak forest with Lespedeza, 25 May 2019, coll. E.P. Kudryavtseva \& S.V. Prokopenko 13417: 21 (VLA).

Distribution: Far East - Amur (rare), S Primorye; East Asia - China, Korea, Japan. Mixed umbrageous forests, forest margins, in shrubs. Described from Japan. This is the third CN count from Russia (see Probatova 2014). Diploid (2x; $=9$ ).

\section{FABACEAE}

Amphicarpaea japonica B. Fedtsch., 2n $=20$

Russia, Far East, Primorskii Krai, Shkotovskii Raion, in vicinity of Novonezhino settlement, Sapfirova canyon, oak forest with Lespedeza, 25 May 2019, coll. E.P. Kudryavtseva \& S.V. Prokopenko 13420: 21 (VLA).

Distribution: Far East (Amur, Primorye, Kurils - Kunashir Isl.); East Asia - Korea, Japan. In broad-leaved forests, forest margins, among shrubs, rarely in meadows, in river valleys. Described from Japan. This species in S Primorye has two chromosome numbers: $2 \mathrm{n}=20$ and 22, both occur on the islands of Peter the Great Bay, near Vladivostok and in Khasanskii Raion (see Probatova 2014). Variable CNs $(2 \mathrm{x} ; \mathrm{x}=10,11)$.

\section{Vicia unijuga A. Braun, 2n $=24$}

Russia, Far East, Primorskii Krai, Shkotovskii Raion, in vicinity of Novonezhino settlement, Sapfirova canyon, oak forest, 25 May 2019, coll. E.P. Kudryavtseva \& S.V. Prokopenko 13419: 21 (VLA).

Distribution: Siberia, Far East - Amur, Primorye, S Sakhalin, S Kurils; Central Asia (Mongolia), East Asia. Mixed and broad-leaved forests, forest margins, among shrubs. Described from Siberia. Multiple CN reports, from Siberia, Far East and adjacent countries - China, Korea, Japan (see Goldblatt \& Johnson 1979+, Rice et al. 2014, Krivenko \& Burlyaeva 2016). There are two ploidy levels within this species $-2 \mathrm{x}, 4 \mathrm{x}(2 \mathrm{n}=12,24)$. Variable ploidy. Tetraploid cytotype mostly occurs in East Asian part of the species area, that would lead to possible taxonomic conclusions (Burlyaeva et al. 2016).

\section{HYPECOACEAE}

\section{Hypecoum erectum L., $2 \mathrm{n}=16$}

Russia, East Siberia, Republic of Buryatia, Tarbagataiskii Raion, right riverside of the Selenga River, Voznesenovka settlement, $503 \mathrm{~m}$ alt., roadside, weedy-ruderal plant community, 13 Jul 2018, coll. D.A. Krivenko 13358: 8 (IRK, VLA).

Distribution: Siberia, Central Asia (Mongolia), East Asia (Northern China). Sandy and rubbly steppes, pebbles in the river valleys, dry Pinus forests, Populus forests, sandstone and limestone rocks, sometimes on waste places. Described from Siberia. Three $\mathrm{CN}$ reports from Baikal Siberia (see Chepinoga 2014). Diploid (2x; $x=8)$.

\section{IRIDACEAE}

Iris halophila Pall., $2 \mathrm{n}=44$

Russia, West Siberia, Altaiskii Krai, Rubtzovskii Raion, left riverside of the Alei River, near Zakharovo settlement, saline 
meadow, 18 Sep 2018, coll. D.A. Krivenko 13372: 9 (VLA).

Distribution: SE Europe, W Siberia, Kazakhstan, Middle Asia, Central Asia (Mongolia). Saline steppe meadows, riverside salt meadows, in Achnatherum splendens communities. Described from Kazakhstan (Kulundinskaya steppe). Its $\mathrm{CN} 2 \mathrm{n}=44$ was already reported from Altaiskii Krai (Doronkin 1987). Tetraploid (4x; $\mathrm{x}=11)$.

\section{LAMIACEAE}

\section{Galeopsis bifida Boenn., 2n = 32}

Russia, East Siberia, Irkutskaya Oblast', Slyudyanskii Raion, W coast of the Baikal Lake, 94th kilometer of Krugobaikal'skaya railway road, $456 \mathrm{~m}$ alt., lakeside, 14 Sep 2018, coll. O.Yu. Zavgorodnyaya 13376: 1 (IRK, VLA).

Distribution: Europe, Asia (but alien in the Far East), alien in North America. Common weed, and among shrubs, in forest margins. Described from Europe. The CN is constant, it was studied from W Siberia and Baikal Siberia (see Goldblatt \& Johnson 1979+, Rice et al. 2014). Tetraploid (4x; x = 8).

\section{Lamium album L., 2n = 18}

Russia, East Siberia, Irkutskaya Oblast', Slyudyanskii Raion, W coast of the Baikal Lake, 94th kilometer of Krugobaikal'skaya railway road, $456 \mathrm{~m}$ alt., lakeside, 14 Sep 2018, coll. O.Yu. Zavgorodnyaya 13367: 1 (IRK, VLA).

Distribution: Europe, Caucasus, Siberia, West Asia. Meadows, in forests and among shrubs, on shadow places, sometimes as a ruderal plant in settlements. Described from Europe. The $\mathrm{CN}$ was reported from West Sayan, Putorana Plateau and East Sayan: 2n = 18 (Goldblatt \& Johnson 1979+, Rice et al. 2014). Diploid (2x; $x=9)$.

\section{Lycopus exaltatus L. $\mathrm{f} ., 2 \mathrm{n}=22$}

Russia, West Siberia, Altaiskii Krai, Rubtzovskii Raion, near Bezrukavka village, left riverside of the Alei River, forb-bluegrass meadow, 18 Sep 2018, coll. D.A. Krivenko 13360: 10 (IRK, VLA).

Distribution: Europe, Siberia, West and Middle Asia. Occurs in flood plains, bogs, meadows, forest edges. Described from Italy. First CN report from Altai. The CN $2 \mathrm{n}=$ 22 is constant in this genus. Diploid $(2 \mathrm{x} ; \mathrm{x}=11)$.

\section{LILIACEAE}

\section{Lilium pumilum Redouté, $2 \mathrm{n}=24$}

Russia, East Siberia, Irkutskaya Oblast', Slyudyanskii Raion, W coast of the Baikal Lake, 94th kilometer of Krugobaikal'skaya railway road, $456 \mathrm{~m}$ alt., lakeside, 14 Sep 2018, coll. O.Yu. Zavgorodnyaya 13377: 1 (IRK, VLA).

Distribution: Middle and East Siberia, Far East, Central Asia (Mongolia), East Asia (NE China, Korean Peninsula). On the rocks in forest belt, steppe meadows. Described from cultivated plants. The $\mathrm{CN}(2 \mathrm{n}=24)$ was many times reported, incl. from Baikal Siberia (see Chepinoga 2014). Diploid $(2 \mathrm{x} ; \mathrm{x}=12)$.

\section{MELANTHIACEAE}

Anticlea sibirica (L.) Kunth (三 Zigadenus sibiricus (L.) A. Gray), 2n = 32

Russia, East Siberia, Irkutskaya Oblast', Irkutskii Raion, SW coast of the Baikal Lake, Kharghino Bay, $463 \mathrm{~m}$ alt., lakeside, 28 Aug 2018, coll. O.Yu. Zavgorodnyaya 13378: 11 (IRK, VLA).

Distribution: East Europe, Siberia, Far East; East Asia. Described from Siberia. In high-mountain matted slopes, on the rocks, in coniferous, mixed and deciduous forests, clearings, in light Larix or dwarf Betula forests. Calciphilous plant. Its $\mathrm{CN}$ was studied many times from the Middle and East Siberia $(2 \mathrm{n}=32$ - see Goldblatt \& Johnson 1979+, Rice et al. 2014). Tetraploid (4x; $x=8)$.

\section{PLANTAGINACEAE}

\section{Plantago depressa Willd., 2n = 12}

Russia, East Siberia, Republic of Buryatia, Tarbagataiskii Raion, right riverside of the Selenga River, Voznesenovka settlement, $503 \mathrm{~m}$ alt., roadside, weedy-ruderal plant community, 13 Jul 2018, coll. D.A. Krivenko 13382: 8 (VLA).

Distribution: Siberia, Far East (mainly southern continental part); Middle Asia, Central Asia, East Asia. Meadows, saline meadows, steppe meadows, grassy slopes, light forests, fallows, riversides, roadsides. Described on cultivated plants. Multiple CN reports (incl. from Baikal Siberia): 2n = 12 (see Goldblatt \& Johnson 1979+, Rice et al. 2014). Diploid $(2 \mathrm{x} ; \mathrm{x}=6)$.

\section{Plantago salsa Pall., 2n = 12}

Russia, West Siberia, Altaiskii Krai, Aleiskii Raion, 2 km W of the railway station Yazevka Sibirskaya, right riverside of the Sukhnev Log River (left tributary of the Yazevka River), forb-grass saline steppe, 24 Sep 2018, coll. D.A. Krivenko 13355: 7 (IRK, VLA).

Distribution: Europe, Caucasus, Middle and Minor Asia, S Siberia, Far East (alien in Chukotka), Central Asia (Mongolia), W China. Saline meadows in the steppe zone, saline lakesides in the river valleys. Described from the south of the Yenisei Siberia. First CN report from Altai. Diploid $(2 x ; x=6)$.

\section{POACEAE}

\section{Dactylis glomerata L., 2n $=28$}

Russia, West Siberia, Altaiskii Krai, Rebrikhinskii Raion, $1 \mathrm{~km} \mathrm{NE}$ of the railway station Rebrikha, the Trubachikha River, Calamagrostis-forb meadow along the riverside, 26 Sep 2018, coll. D.A. Krivenko 13357: 12 (IRK, VLA).

Distribution: almost Holarctic, but absent in Arctic regions, and only as alien or naturalized - in the Far East of Russia. Meadows, clearings, light forests, roadsides, in settlements, cultivated as fodder or lawn plant. The limit of its natural area of distribution in Russia - Transbaikalia. Described from Europe. Many CN reports (see Goldblatt \& Johnson 1979+, Rice et al. 2014) give tetraploid CN 2n = 28. This is the first CN count in D. glomerata from Altai. Tetraploid (4x; $=7$ ). In the Altai Mts (middle and upper belts) D. altaica Besser occurs, but its $\mathrm{CN}$ still remains unknown.

Elymus caninus (L.) L., $2 \mathrm{n}=28$

Russia, West Siberia, Altaiskii Krai, Rebrikhinskii Raion, $1 \mathrm{~km} \mathrm{NE}$ of the railway station Rebrikha, the Trubachikha River, Calamagrostis-forb meadow along the riverside, $26 \mathrm{Sep}$ 2018, coll. D.A. Krivenko 13363: 12 (IRK, VLA). 
Distribution: Europe, Asia, but absent in the Far East of Russia; alien in North America. The limit of its natural area of distribution in Russia is in Transbaikalia. In forests, forest margins and clearings, among shrubs, sometimes in subalpine meadows and stony slopes, up to the upper mountain belt. Described from Europe. Its $\mathrm{CN}$ was studied several times in Russia $-2 \mathrm{n}=28$, from Karelia and West Siberia (see Goldblatt \& Johnson 1979+, Rice et al. 2014), but from Altai its $\mathrm{CN}$ is reported now for the first time. Tetraploid (4x; $\mathrm{x}=7)$ like most of Elymus spp.

Koeleria cristata (L.) Pers., $2 \mathrm{n}=28$

Russia, West Siberia, Altaiskii Krai, Aleiskii Raion, 4 km NW of Krasnyi Yar settlement, right riverside of the Solonovka River (left tributary of the Alei River), Artemisia-Stipa steppe, 24 Sep 2018, coll. D.A. Krivenko 13424: 25 (VLA).

Distribution: Europe, Caucasus, Siberia, Far East (S of continental part); Middle, Central and East Asia, N America. Described from Europe. Steppes, meadows, forest clearings, stony slopes and rocks, up to middle mountain belt. Polymorphous species. Multiple CN counts, however it is still not clear if this species is represented by both di- and tetraploid levels. The majority of $\mathrm{CN}$ reports from Russia gives $2 \mathrm{n}=28$, in Baikal Siberia - only $2 \mathrm{n}=28$ (see Chepinoga 2014), but for Altai only $2 n=14$ was indicated (see Goldblatt \& Johnson 1979+, Rice et al. 2014). In Primorye $-2 \mathrm{n}=14$, only one report of $2 \mathrm{n}=28$ (see Probatova 2014). Variable ploidy (2x, 4x; $x=7)$.

\section{Milium effusum L., $2 \mathrm{n}=28$}

Russia, East Siberia, Irkutskaya Oblast', Slyudyanskii Raion, W coast of the Baikal Lake, 94th kilometer of Krugobaikal'skaya railway road, right riverside of the Pylovka River, 636 m alt., in forest, 12 Sep 2018, coll. O.Yu. Zavgorodnyaya 13370: 1 (VLA).

Distribution: almost Holarctic (but absent in Arctic regions). Forest species. Described from Europe. Multiple $\mathrm{CN}$ counts (forth of them are from Baikal Siberia) give (see Chepinoga 2014) tetraploid CN - 2n $=28$ (4x; $\mathrm{x}=7)$.

Phragmites stenophyllus (Boiss.) Rouy ex Prain, $2 \mathrm{n}=48$

Russia, West Siberia, Altaiskii Krai, Aleiskii Raion, 2 km W of the railway station Yazevka Sibirskaya, right riverside of the Sukhnev Log River (left tributary of the Yazevka River), forb-grass saline steppe, 24 Sep 2018, coll. D.A. Krivenko 13362: 7 (IRK, VLA).

Distribution: Mediterranean. Saline habitats. Described from SW Asia. First CN count from Russia. Tetraploid $(4 \mathrm{x} ; \mathrm{x}=12)$.

Puccinellia tenuissima (Litv. ex V.I. Krecz.) Litv. ex Pavlov, $2 \mathrm{n}=14$

Russia, West Siberia, Altaiskii Krai, Aleiskii Raion, 2 km W of the railway station Yazevka Sibirskaya, right riverside of the Sukhnev Log River (left tributary of the Yazevka River), forb-grass saline steppe, 24 Sep 2018, coll. D.A. Krivenko 13371: 7 (IRK, VLA).

\section{$-2 \mathrm{n}=28^{*}$}

Russia, West Siberia, Altaiskii Krai, Rebrikhinskii Raion, $7 \mathrm{~km} \mathrm{~W}$ of Rozhnev Log settlement, grassy steppe meadow, 27 Sep 2018, coll. D.A. Krivenko 13375: 13 (IRK, VLA).
Distribution: SE Europe, Siberia, Central Asia, alien elsewhere. Saline habitats. Described from Kazakhstan. The tetraploid $\mathrm{CN}-2 \mathrm{n}=28$ is new for the species: only $2 \mathrm{n}=14$ (from Altai) was known before. P. tenuissima as well as P. tenuiflora (Griseb.) Scribn. et Merr. and P. macranthera V.I. Krecz. (see Ovchinnikova \& Probatova 2015a) have two ploidy levels within one species (2x and 4x; 4x and $8 x$, respectively). Variable ploidy. Not constant $\mathrm{CNs}$ are rare in Puccinellia spp. Recently such instability of $\mathrm{CN}$ was observed also in Far Eastern species P. tovelevii Ovchinnikova et Prob.: $2 n=28$ and 42, this species likely has hybrid origin (Ovchinnikova \& Probatova 2015b). Variable ploidy (2x, 4x; $x=7)$.

Setaria pumila (Poir.) Roem. et Schult., $2 \mathrm{n}=36$

Russia, West Siberia, Altaiskii Krai, Pospelikhinskii Raion, near Kotlyarovka settlement, 20 Sep 2018, coll. D.A. Krivenko 13359: 14 (IRK, VLA).

Distribution: Cosmopolite (except Arctic regions). Weedy species. Described from France or America. First $\mathrm{CN}$ count from Altai. This is the most common and wellknown $\mathrm{CN}$ for this species. Rarely the diploid CN 2n $=18$ also occurs (Amurskaya Oblast' - Probatova et al. 2013). Tetraploid $(4 \mathrm{x} ; \mathrm{x}=9)$. Variable ploidy $(2 \mathrm{x}, 4 \mathrm{x} ; \mathrm{x}=9)$.

\section{RANUNCULACEAE}

\section{Anemone sylvestris L., $2 \mathrm{n}=16$}

Russia, East Siberia, Irkutskaya Oblast', near Angarsk city, left riverside of the Kitoi River, $455 \mathrm{~m}$ alt., light forb-grass Pinus forest, 16 Jul 2018, coll. D.A. Krivenko, O.A. Chernysheva \& M.V. Kostina 13392: 15 (IRK, VLA).

Distribution: Europe, Siberia; Central and East Asia. Meadows, open slopes, forest edges, light forests, forb steppes. Described from Central Europe. The CN was studied from West Siberia (Tomskaya Oblast'), Baikal Siberia and Yakutia: 2n = 16 (see Goldblatt \& Johnson 1979+, Rice et al. 2014). Diploid (2x; $x=6)$.

\section{Aquilegia sibirica Lam., 2n $=14$}

Russia, West Siberia, Altai Republic, Ulaganskii Raion, [the riverside of] Chibit River, 5 Jul 2019, coll. A.S. Erst, T.V. Erst, K. Xiang \& L. Lian 021: 16 (NS).

Distribution: Siberia, Middle Asia, Central Asia (Mongolia). Forest edges and clearings, light forests, up to highmountains. Described from Siberia. The CN 2n = 14 was reported from Siberia (Buryatia and Tyva republics - Friesen 1991, Agapova et al. 1993). First CN count from Altai. Diploid (2x; $\mathrm{x}=7)$.

Paraquilegia microphylla (Royle) J.R. Drumm. et Hutch., $2 \mathrm{n}=14$

Russia, West Siberia, Altai Republic, Ulaganskii Raion, Aktash mine, $3054 \mathrm{~m}$ alt., 10 Aug 2018, coll. A.S. Erst \& T.V. Erst 129: 17 (NS).

Distribution: Siberia; Middle Asia, Central Asia. In high-mountains on placers, rock fissures. Described from Himalayas. There were $4 \mathrm{CN}$ reports from Baikal Siberia (see Chepinoga 2014). First CN count from Altai. Diploid $(2 \mathrm{x} ; \mathrm{x}=7)$. The $\mathrm{CN}$ is constant.

\section{Thalictrum foetidum L., $2 \mathrm{n}=14$}

Russia, East Siberia, Irkutskaya Oblast', Irkutskii Raion, SW coast of the Baikal Lake, Kharghino Bay, $463 \mathrm{~m}$ alt., 
lakeside, 28 Aug 2018, coll. O.Yu. Zavgorodnyaya 13379: 11 (IRK, VLA).

Distribution: Europe, Siberia, Far East; Central and East Asia. Light Betula and Larix forests, forest edges and meadows. Described from Europe. The CN of T. foetidum was already studied from Altai, Baikal Siberia and Yakutia (Goldblatt \& Johnson 1979+, Rice et al. 2014). The CN is constant. Diploid (2x; $x=7)$.

\section{ROSACEAE}

Chamaerhodos erecta (L.) Bunge, 2n = 14

Russia, East Siberia, Republic of Buryatia, Tarbagataiskii Raion, right riverside of the Selenga River, Voznesenovka settlement, $503 \mathrm{~m}$ alt., roadside, weedy-ruderal plant community, 13 Jul 2018, coll. D.A. Krivenko 13411: 8 (VLA).

Distribution: Siberia, Far East; Middle Asia, Central Asia (Mongolia), East Asia (Northern China). Mountain dry stony slopes, on sands, pebbles, in pine forests. Described from Dahuria. The CN of C. erecta was studied from Tyva and Yakutia republics: $2 \mathrm{n}=14$. The $\mathrm{CN}$ is constant. Diploid $(2 \mathrm{x} ; \mathrm{x}=7)$.

\section{SCROPHULARIACEAE}

\section{Linaria acutiloba Fisch. ex Rchb., 2n = 12}

Russia, East Siberia, Irkutskaya Oblast', Irkutskii Raion, SW coast of the Baikal Lake, Kharghino Bay, $463 \mathrm{~m}$ alt., lakeside, 28 Aug 2018, coll. O.Yu. Zavgorodnyaya 13364: 11 (IRK, VLA).

Distribution: East Europe, Siberia, Far East; Central Asia (Mongolia), East Asia (China). Meadows, steppes, riverside stony slopes, abandoned fields. Described from Dahuria. Diploid $(2 x ; x=6)$. Four reports from Baikal Siberia (see Chepinoga 2014). The $\mathrm{CN}$ is constant.

\section{VIOLACEAE}

\section{Viola mandshurica W. Becker, 2n $=48$}

Russia, Far East, Primorskii Krai, Shkotovskii Raion, in vicinity of Novonezhino settlement, Sapfirova canyon, meadow, 25 May 2019, coll. E.P. Kudryavtseva \& S.V. Prokopenko 13415: 21 (VLA).

Distribution: Far East: Amur, Primorye, S Kurils; East Asia: China, Korea, Japan. Oak forests, forest clearings, among shrubs, rubbly and grassy slopes near the seacoast, dry meadows and abandoned fields. Described from surroundings of Vladivostok. In this species the $\mathrm{CN} 2 \mathrm{n}=48$ is the most common, however once the tetraploid $\mathrm{CN} 2 \mathrm{n}$ = 24 was also reported (see Probatova 2014). The CNs of the Far Eastern Viola were compiled and discussed in the special paper (Probatova et al. 2001). Variable ploidy (4x (?), $8 \mathrm{x} ; \mathrm{x}=6)$.

\section{CONCLUSION}

Most of the species studied $-24(53 \%)$ are diploids, with different basic numbers: $\mathrm{x}=6,7,8,9,10,11,12$, 13. The 14 species have tetraploid $\mathrm{CNs}$, one of the rest (Chenopodium album) is hexaploid. The $\mathrm{CN}$ is first studied in Trigonotis peduncularis. The first CN counts from Russia - in Amblynotus rupestris and Phragmites stenophyllus. Nine species - Allium splendens, Bupleurum bicaule, Koeleria cristata,
Neotorularia bumilis, Puccinellia tenuissima, Setaria pumila, Suaeda kulundensis, Vicia unijuga, Viola mandshurica have variable ploidy, and in Amphicarpaea japonica the basic $\mathrm{CN}$ is not constant. Eight species are studied for the first time from Altai, Bupleurum bicaule, Conioselinum tataricum - from Baikal Siberia, Neotorularia humilis and Minuartia laricina - from Primorskii Krai. In Suaeda kulundensis and Puccinellia tenuissima new cytotypes (4x) are revealed from Altai plants.

\section{ACKNOWLEDGEMENTS}

The authors are grateful to E.G. Rudyka for participation in chromosome numbers determinations, as well as to M.N. Lomonosova and S.V. Ovchinnikova for assistance in identifying some plant species. The research was supported by Russian Science Foundation according to the research Project № 19-74-10082.

\section{LITERATURE CITED}

Agapova, N.D., K.B. Arkharova, L.I. Vakhtina, L.I. Zemskova \& L.V. Tarvis 1993. Chromosome numbers in flowering plants of the flora of the USSR: family Moraceae-Zygophyllaceae. Nauka, St. Petersburg, 430 pp. (in Russian). [Агапова Н.А., Архарова К.Б., Вахтина А.И., Земскова Е.А., Тарвис А.В. 1993. Числа хромосом цветковых растений фморы CССР: семейства Moraceae-Zygophyllaсеае. СПб: Наука. 430 с.].

Bolkhovskikh, Z.V., V.G. Grif, O.I. Zakhareva \& T.S. Matveeva 1969. Chromosome numbers of flowering plants. Nauka, Leningrad, 926 pp. (in Russian). [Болховских 3.B., Гриф В.Г., Захарьева О.И., Матвеева Т.С. Хромосомные числа цветковых растений. А.: Наука. 926 с.].

Burlyaeva, M.O., D.A. Krivenko, E.M. Machs \& A.S. Sabitov 2016. Polymorphism of some species from the tribe Vicieae Bronn (Fabaceae Lindl.) according to the data of morphological and molecular genetic analysis. Trudy po prikladnoi botanike, genetike i selektsii 177(4):79-91. (in Russian). [Бурляева М.О., Кривенко А.А., Мачс Э.М., Сабитов А.Ш. 2016. Полиморфизм некоторых виАов трибы Vicieae Bronn (Fabaceae Lindl.) по Аанным морфологического и молекулярно-генетического анализов // Труды по прикладной ботанике, генетике и семекции. Т. 177, № 4. С. 79-91].

Chepinoga, V.V. 2014. Chromosome numbers of plant species from Baikal Siberia. Nauka, Novosibirsk, 418 pp. (in Russian). [Чепинога В.В. 2014. Хромосомные числа растений фморы Байкальской Сибири. Новосибирск: Наука. 418 c.].

Doronkin, V.M. 1987. Iridaceae. In: Flora of Siberia: AraceaeOrchidaceae, vol. 4 (L.I. Malyshev \& G.A. Peshkova, eds), pp. 113-125, Nauka, Novosibirsk (in Russian). [Аоронькин B.M. 1987. Iridaceae // Фмора Сибири: Araceae-Orchidaceae, т. 4 / под реА. А.И. Малышева и Г.А. Пешковой. Новосибирск: Наука. С. 113-125].

Friesen, N.V. 1991. Chromosome numbers in members of the Ranunculaceae family from Siberia. Botanicheskii Zhurnal 76(6):905-907 (in Russian). [Фризен Н.В. Числа хромосом преАставителей семейства Ranunculaceae из Сибири // Ботанический журнал. Т. 76, № 6. С. 905-907].

Goldblatt, P. \& D.E. Johnson (eds) 1979+. Index to plant chromosome numbers (IPCN). Missouri Botanical Garden, St. Louis. Available from: http://www.tropicos.org/Project/ IPCN. Last accessed 22.09.2019.

Krasnikov, A.A. \& D.N. Schaulo 1990. Chromosome numbers in representatives of some families of vascular plants in the flora of the Novosibirsk region. II. Botanicheskii 
Zhurnal 75(1):118-120 (in Russian). [Красников A.A., Шауло А.Н. Числа хромосом представителей некоторых семейств сосудистых растений флоры Новосибирской области. II. // Ботанический журнал. Т. 75, № 1. C. 118-120].

Krasnikov, A.A., O.S. Zhirova, M.N. Lomonosova \& S.V. Smirnov 2003. Chromosome numbers of Asteraceae from the southern Siberia and Kazakhstan. Botanicheskii Zhurnal 88(9):151-153 (in Russian). [Красников A.A., Жирова О.С., Аомоносова М.Н., Смирнов С.В. 2003. Числа хромосом представителей семейства Asteraceae из Южной Сибири и Казахстана // Ботанический журнал. Т. 88, № 9. С. 151-153].

Krivenko, D.A. \& M.O. Burlyaeva 2016. IAPT/IOPB chromosome data 22 (K. Marhold, ed.). Taxon 65(5):1202, E 8-9.

Lomonosova, M. \& H. Freitag 2009. IAPT/IOPB chromosome data 8 (K. Marhold, ed.). Taxon 58(4):1284, E1011.

Lomonosova, M.N. \& A.A. Krasnikov 1992. Chromosome numbers in the members of the genus Atriplex (Chenopodiaceae). Botanicheskii Zhurnal 77(6):99-100. (in Russian). [Аомоносова М.Н., Красников А.А. Числа хромосом представителей рода Atriplex (Chenopodiaceae) // Ботанический журнал. Т. 77, № 6. С. 99-100].

Lomonosova, M.N. \& D.N. Shaulo 2010. Karyology of the Siberian representatives of the family Chenopodiaceae.

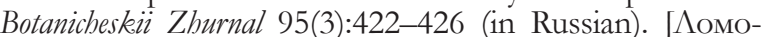
носова М.Н., Шауло А.Н. 2010. Кариология преАставителей семейства Chenopodiaceae из Сибири // Ботанический журнал. Т. 95, №. 3. С. 422-426].

Lomonosova, M.N. 2018. Contribution to chromosome study in some vascular plants from Russia: Chenopodiaceae, Amaranthaceae, Brassicaceae. Botanica Pacifica 7(2): 151-156.

Lomonosova, M.N., A.A. Krasnikov \& S.A. Krasnikova 2001. Chromosome numbers of Chenopodiaceae from Siberia. Botanicheskii Zhurnal 86(9):145-146 (in Russian). [^омоносова М.Н., Красников А.А., Красникова С.А. Числа хромосом видов семейства Chenopodiaceae из Сибири // Ботанический журнал. Т. 86, № 9. С. 145-146].

Lomonosova, M.N., S.A. Krasnikova, A.A. Krasnikov, A.L. Ebel \& N.A. Rudaja 2003. Chromosome numbers of the family members Chenopodiaceae representatives from Mongolia and Kazakhstan. Botanicheskii Zhurnal 88(8):113-115 (in Russian). [Аомоносова M.H., Красников А.А., Красникова С.А. Эбель А.А., Рудая Н.А. Числа хромосом представителей семейства Chenopodiaceae из Монголии и Казахстана // Ботанический журнал. Т. 88, № 8. С. 113-115].

Ma, X.H., X.Q. Ma \& N. Li 1990. Chromosome observation of some drug plants in Xinjiang. Acta Botanica BorealiOccidentalia Sinica 10(3):203-210.

Ovchinnikova, S.V. \& N.S. Probatova 2015a. Chromosome numbers in species of the genus Puccinellia (Poaceae) of Russia and adjacent countries in connection to taxonomy. Rastitel'nyi mir Aziatskoi Rossii 2(18):56-67 (in Russian). [Овчинникова С.В., Пробатова Н.С. 2015a. Хромосомные числа видов рода Puccinellia (Poaceae) России и сопредельных государств в связи с таксономией // Растительный мир Азиатской России. № 2(18). C. 56-67].
Ovchinnikova, S.V. \& N.S. Probatova 2015b. New species of the genus Puccinellia Parl. (Poaceae) from the Russian Far East. Rastitel'nyi mir Aziatskoi Rossii 1(17):33-38 (in Russian). ГОвчинникова C.В., Пробатова Н.С. 2015b. Новый вил рода Puccinellia Parl. (Poaceae) с Аальнего Востока России // Растительный мир Азиатской России. № 1(17). С. 33-38].

Pimenov, M.G. \& T.A. Ostroumova 2012. Umbelliferae of Russia. KMK Scientific Press, Moscow, 477 pp. (in Russian). [Пименов М.Г., Остроумова Т.А. 2012. Зонтичные (Umbelliferae) России. Москва: Товарищество научных изАаний КМК. 477 с.].

Probatova, N.S. 2014. Chromosome numbers in vascular plants of the Primorskii Krai (Russian Far East). Dal'nauka, Vladivostok, 343 pp. (in Russian). [Пробатова H.C. 2014. Хромосомные числа сосудистых растений Приморского края (Аальний Восток России). ВАадивосток: Аальнаука. 343 с.].

Probatova, N.S., A.V. Verkhozina, E.G. Rudyka \& D.A. Krivenko 2013. IAPT/IOPB chromosome data 16 (K. Marhold ed.). Taxon 62(6):1360-1361, E13-14.

Probatova, N.S., E.G. Rudyka, V.Yu. Barkalov, I.A. Nesterova, S.G. Kudrin \& E.A. Chubar' 2006. Chromosome numbers in vascular plants from the nature reserves of Primorskii Krai and Amur River basin. Botanicheskii Zhurnal 91(7):1117-1134 (in Russian). [Пробатова H.C., Рудыка Э.Г., Баркалов В.Ю., Нестерова И.А., Кудрин С.Г., Чубарь Е.А. 2006. Числа хромосом сосуАистых растений из заповеАников Приморского края и Приамурья // Ботанический журнал. Т. 91, № 7. C. 1117-1134].

Probatova, N.S., S.G. Kazanovsky, E.G. Rudyka, V.P. Seledets \& V.A. Nechaev 2012. IAPT/IOPB chromosome data 13 (K. Marhold ed.). Taxon 61(4):899-902, E 34-42.

Probatova, N.S., T.A. Bezdeleva \& E.G. Rudyka 2001. Chromosome numbers, taxonomy and distribution of the Far Eastern Viola (Violaceae). Komarovskie chteniya 48:85-124 (in Russian). [Пробатова Н.С., Безделева Т.А., Рудыка Э.Г. 2001. Числа хромосом, таксономия и распространение дальневосточных фиалок (Viola, Violaceae) // Комаровские чтения. Вып. 48. С. 85-124].

Probatova, N.S., V.Yu. Barkalov \& E.G. Rudyka 2007. Caryology of the flora of Sakhalin and the Kurile Islands. Chromosome numbers, taxonomic and phytogeographical comments. Dal'nauka, Vladivostok, 392 pp. (in Russian). [Пробатова H.C., Баркалов В.Ю., Рудыка Э.Г. 2007. Кариология флоры Сахалина и Курильских островов. Числа хромосом, таксономические и фитогеографические комментарии. ВАадивосток: АаАьнаука. 392 с.].

Rice, A., L. Glick, S. Abadi, M. Einhorn, N.M. Kopelman, A. Salman-Minkov, J. Mayzel, O. Chay \& I. Mayrose 2014. The Chromosome Counts Database (CCDB) - a community resource of plant chromosome numbers. New Phytologist 206(1):19-26. Available from: http://ccdb.tau. ac.il/ Last accessed 22.09.2019.

Stepanov, N.V. \& E.N. Muratova 1995. Chromosome numbers of some taxa of higher plants of Krasnoyarsk territory. Botanicheskii Zhurnal 80(6):114-116 (in Russian). [Степанов Н.В., Муратова Е.Н. Числа хромосом некоторых таксонов высших растений Красноярского края // Ботанический журнац. 1995. Т. 80, № 6. С. 114-116]. 